COMMENT

ZOOS' PRINT JOURNAL 20(5): 1879

\section{COMMENTS ON "AVIFAUNA OF THRISSUR DISTRICT, KERALA, INDIA" BY JAYSON ET AL.}

\section{Sashikumar}

9,Subhash Nagar, Kannur, Kerala 670 002, India

Email: csashikumar@rediffmail.com

I am writing this letter with regard to the paper published in the Zoos' Print Journal, February 2005 titled "Avifauna of Thrissur District, Kerala, India" by Jayson E.A. and C.I. Sivaperuman and would like to point out certain inaccuracies in the paper concerning certain species of birds listed.

1. Masked Booby Sula dactylatra: This is a pelagic bird, which reaches our coast and occasionally inlands during monsoon gales. This has been classified as a migrant in this paper

2. Spot-billed Pelican Pelecanus philippensis: As far as I know, there was only a single record of this species from the Kole (Ravindran, 1995). Obviously this species is a straggler and not a resident of the area.

3. Ferruginous Pochard Aythya nyroca: Details of the sightings of this species is not given; as far as Kerala is concerned, this species is extremely rare, with no recent sightings, though it is included in Birds of Kerala (Ali, 1969).

4. Jungle Bush-Quail Perdicula asiatica: Shown as present at KFRI Campus, KAU Campus and Peechi-Vazhani Sanctuary. The habitat of this bird is dry scrub (e.g. Chinnar Wildlife Sanctuary) and this species is unlikely to be seen at the above-mentioned places. More details desirable.

5. Wood Snipe Gallinago nemoricola and Woodcock Scolopax rusticola: Shown as seen at the Kole wetlands. Both are birds of damp areas in the forest with very few recent sightings; unlikely to be seen in Kole wetlands.

6. Spoon-billed Sandpiper Calidris pygmeus: Area seen not specified. This is one of the most endangered waders and the whole of the west coast has only one record (Uthaman \& Namassivayn, 1991). More details wanted.

7. Indian Courser Cursorius coromandelicus: No records from Kerala for the last several years and its habitat 'bare wasteland with scattered scrub' hardly exists here.

8. Lesser Black-backed Gull Larus fuscus: This species has been deleted from the Indian list (Grimmett et al., 1998; Kazmierczak, 2000; Manakkadan \& Pittie, 2001).

9. Tree Pipit Anthus trivialis: Shown as seen in the Kole wetlands. This species is found in 'well shaded plantations of tea, coffee and cardamom' above 900m (Ali, 1969).

10. Common Babbler Turdus caudatus: Shown as occurring in the Kole wetlands!!! This is the most 'uncommon babbler' of Kerala and has to be deleted from the state list, as there is no suitable habitat for it.

11. Bengal Bushlark Mirafra assamica: The Bushlark occurs in the Gangetic plain to Arunachal Pradesh, Manipur and Burma. The species we have here in southern India is Jerdon's Bushlark Mirafra affinis.
12. Plain Martin Riparia paludicola: Reported first in Kerala from the Kole wetlands by V. Santharam (Neelakantan et al., 1993). Here, it is shown as occurring in Peechi-Vazhani Wildlife Sanctuary.

Some other species, which according to this paper, said to occur in the Kole wetlands also need to be explained with more details. They are: Eurasian Sparrowhawk Accipiter nisus, Pallid Harrier Circus macrourus, Grey Francolin Francolinus pondiceranus, Eurasian Collared Dove Streptopelia decaocta, Small Sunbird Nectarinia minima, White-bellied Drongo Dicrurus caerulescens etc. Interestingly, the authors have omitted some of the most significant sightings at the Kole, e.g. White-tailed Lapwing Vanellus leucurus, Grey-headed Lapwing Vanellus cinereus (Ravindran, 2001; Ravindran \& Nameer, 2001).

\section{REFERENCES}

Ali, S. (1969). Birds of Kerala. OUP, Delhi.

Grimmett, R., C. Inskipp and T. Inskipp (1998). Birds of the Indian Subcontinent. OUP, Delhi.

Kazmierczak, K. (2000). A Field Guide to the Birds of India, Sri Lanka,Pakistan, Nepal, Bhutan, Bangladesh and Maldives. Om Book Service, New Delhi.

Manakkadan, R. and A. Pittie (2001). Standardised common and scientific names of the Birds of the Indian Subcontinent. Buceros 6(1). Ravindran, P.K. (1995). The Kole Wetlands - an avian paradise in Kerala. Newsletter for Birdwatchers 35(1): 2-5.

Ravindran, P.K. (2001). Sighting of the White-tailed Lapwing Vanellus leucurus (Lichtenstein) in Thrissur District, Kerala. Journal of the Bombay Natural History Society 98(2): 279.

Ravindran, P.K. and P.O. Nameer (2001). Grey-headed Lapwing Vanellus cinereus (Blyth) (Family Charadriidae) in Kerala. Journal of the Bombay Natural History Society 98(3): 450.

Uthaman, P.K. and L. Namassivayam (1991). The birdlife of Kadalundi Estuary. Blackbuck 7(1): 3-11.

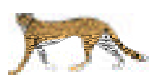

RESPONSE

ZOOS' PRINT JOURNAL 20(5): 1879-1880

\section{REPLY TO THE COMMENTS BY SASHIKUMAR ON "AVIFAUNA OF THRISSUR DISTRICT, KERALA, INDIA"}

\section{E.A. Jayson and C. Sivaperuman}

Division of Forest Ecology and Biodiversity Conservation, Kerala Forest Research Institute, Peechi, Thrissur, Kerala 680653, India Email: jayson@kfri.org

This is with reference to the comments made by Sashikumar on the Avifauna of Thrissur District, Kerala, India. The paper is a checklist compiled from our fieldwork and from published information collected from reports and research papers. We would like to point out that the bird species included in the Kole wetlands list include the sightings from different microhabitats like mud flats, shallow water, open water, bunds, floating vegetation, grasslands, canals and adjacent coconut and rubber plantations which is found in the Kole wetlands and adjacent areas.

1. Sula dactylatra: This species marked as Migrant (M) based on Ali and Ripley (1983).

(C) Zoo Outreach Organisation; www.zoosprint.org Response to comments received 22 March 2005; Edited and accepted 10 April 2005; Date of publication 21 April 2005 